\title{
CAUDILLO DE ESPAÑA: VIRIATHUS, TRAJAN, FRANCO
}

\author{
Oliver Baldwin ${ }^{1}$ \\ https://doi.org/10.18778/8220-421-6.17
}

\begin{abstract}
The dictatorship of General Franco in Spain resorted to two characters of ancient Iberian history to promote Franco's authoritarianism: Viriathus and Trajan. In the early years of the regime, Viriathus was often called "caudillo de los españoles". The anachronic distinction was obviously meant to mirror Franco's own title as Caudillo de España. Trajan, on the other hand, appeared as an Iberian conqueror and excellent, military, ruler, thus serving as a predecessor to another Iberian army general in power: Franco himself. These lines analyse how Trajan and Viriathus appeared, in Francoist propaganda and education, as two complementing precedents (internal and external, local and universal) of the greatest and final Caudillo de España, Franco.
\end{abstract}

Keywords: Francoism, Viriathus, Trajan, Antiquity, caudillo.

Many Western European nations have seen themselves as heirs to the glory of republican or imperial Rome, and even its continuators. The reasons for this are many, from territorial divisions already established in Roman times to national legitimation, cultural identity or imperial pretentions. Conversely, those tribes or communities who had fought against Roman imperialism became national freedom or resistance fighters in national discourses, clearly demonstrating the nation's will for independence and national identity. Rome thus shaped national rhetorics that

1 British Academy Postdoctoral Fellow at the Department of Classics, University of Reading. o.a.baldwin@reading.ac.uk 
were at once historical and universal and also essentialist and independent.

Spain was not a stranger to these rhetorics. It too used Rome and its impact on the Iberian Peninsula to understand what Spain had been, was and ought to be. Both a Roman and an anti-Roman discourse explained Spain's existence and essence. Said development can, for example, be seen not only in the territorial legitimation of a unified Spain, apparently a development of a Hispania that territorially never truly existed; it can also be seen in how Angel Ganivet (1897), at the apex of Spain's identity crisis during the $\mathrm{Cu}$ ban War (1895-1898), saw in Seneca the embodiment of Spanishness. Spain thus developed an identity that was also shaped by what Rome had thought of it, how Spain had resisted the Romans and what it had contributed to Roman culture and stately affairs.

As in the cases of Germany, Italy, Portugal and Romania, Spain too had its own nationalistic authoritarian dictatorship in the twentieth century, lasting from 1939 to 1975. The dictatorship of General Francisco Franco, in line with its early sympathies with Fascism and Nazism, also made use of ancient Rome to legitimate not only its own existence, rationale and goals, but also its own visions of what Spain was and ought to be. The personalistic regime of Franco made extensive use of Roman-style dictatorship, auctoritas and imperium, as is most clearly evidenced in Franco's own triumphus in Madrid on the $19^{\text {th }}$ of May 1939, after he had defeated the republican forces: the Desfile de la Victoria (Parade of Victory).

The present lines seek to shed some light on Francoist uses of antiquity to legitimate and promote the dictatorial regime. Given its caesarist nature, headed by the sole command of General Francisco Franco, I shall here focus on one specific, and central, aspect of Francoist discourse: the figure of the Spanish caudillo ${ }^{2}$. As we shall see, the figure of the caudillo, equivalent to a $d u x$ or conductor, but also to the titles of Duce or Führer, became, by virtue of its national and providential leadership, the embodiment of the

2 For the origins, implications and Francoist development of this term see Moradiellos (2016). 
nation expressed in and directed by his own virtues as a magnanimous but implacable, humble military head of the nation: "The word caudillo means chief, natural king, and it has the most Spanish origin", Ruiz Carnero explained in 1943 (1943: 357). I shall focus my attention on two ancient "caudillos" who exemplified, for the regime, its independence and universality, respectively: Viriathus and Trajan. I shall do this by understanding how these two ancient figures appear as Spanish caudillos in the early years of the regime, thus becoming precedents and models for the national importance and relevance of the Caudillo de España, Francisco Franco, to whom the first section is dedicated. Coinciding with the nationalistic motto of the dictatorship, that Spain was "Una, Grande y Libre" (One, Great and Free), I shall structure my exposition by understanding how Viriathus and Trajan served or embodied this vision of Spain ${ }^{3}$.

\section{1.}

\section{Franco: Caudillo de España por la Gracia de Dios}

\section{1 .}

\section{Movimiento Nacional}

Francisco Franco was claimed as Generalísimo de los Ejércitos and Chief of Government in October 1936, just over two months after the military coup in July that began the Spanish Civil War (Payne, 1987: 113-118). Broadly speaking, between 1936 and 1955, the regime went through three major periods: the Civil War (1936-1939), the authoritarian state (1939-1945) and isolationism (1945-1955). The first was shaped by the war and thus driven by a discourse of providential crusade against the enemies of Spain (Payne, 1987: 87-228); the second established the foundations of the regime, with a philo-Fascist character, seeking the fusion of diverse

3 The structure of Una, Grande y Libre was incidently used to divide the History of Spain by Pemán (1939: 5-6) and in a 1939 schoolbook, see Ruiz Zapatero and Álvarez Sanchís (1998: 44). 
factions and sympathy towards the fascist states at war, Germany and Italy (Payne, 1987: 231-342); the third coincided with the end of the Second World War and the repudiation by the allies of the dictatorship, which would soon turn into anti-Communist sympathy, epitomised by Spain's entrance to the UN Assembly in 1955 (Payne, 1987: 343-459). Therefore, the years 1936-1955 are those of the authoritarian development of the regime, responding to the three periods of War, Totalitarianism and Autarchy. The present discussion will focus on these years and its key stages.

The regime wished to bring together five distinctive political families, as they have been known, which had formed Franco's forces in the Civil War: traditionalists, Spanish nationalists, Catholics, the military and the philo-fascist group Falange Española $y$ de las JONS ${ }^{4}$. Franco soon joined the traditionalist, nationalist and Falange sections into a unique national party, Falange Española Tradicionalista y de las JONS, in April 1937 (Payne, 1987: 168-178; Boyd, 1999: 91-92; Duplá, 2003: 76-77; Moradiellos, 2016: 799). It was integrated into a more ephemeral and broader movement known as the Movimiento Nacional (National Movement), the ideological and political locomotive of the regime. Franco thus joined in his own person as caudillo, the leadership of the political Movimiento Nacional and of the Armed Forces. The Church participated actively in Francoist unity, for it bestowed many exceptional privileges on Franco. Therefore, all the variants of the regime converged into one, in Franco's own person as Caudillo de España, Generalísimo de los Ejércitos and providential leader of the national crusade.

\section{2 .}

\section{A providential mission}

The historical discourse of the regime was based primarily on the idea that Spain's History was providential. This idea was best expressed already in 1935 by the founder and leader of Falange

4 For a summary of the political ideas of these families see Moradiellos, 2016: 791-794. 
Española, José Antonio Primo de Rivera, killed in the Civil War. According to Primo de Rivera, the Spanish nation was not its language, or its race or even its territory, but a "unity of destiny within the universal” (Primo de Rivera, 2007: 999). Spain’s providential destiny as a united, imperial and Catholic monarchy had been the pretext by which previous discourse had defended that those who did not ascribe to this idea, or who openly opposed it, were supporters of an anti-Spain, thus not belonging to the true Spain (Álvarez Junco, 2011: 370-375; Boyd, 1999: 93-95). The idea of Spain's destiny also helped in convincing many of the ultimate victory of a Catholic and united Spain against the antiSpain, central to the Spanish Civil War and the dictatorship. The Civil War was, after all, hailed as a "War of National Liberation" or a "National Crusade". Franco himself alluded to his providential mission in his investiture speech on the $1^{\text {st }}$ of October 1936 in Burgos:

You are placing Spain in my hands. My hand will be firm, my pulse will not tremble, and I shall try to raise Spain to the place that corresponds to her history and her rank in earlier times (Quoted and translated in Payne, 1987: 117).

But besides the ideological implications of the idea of a "unity of destiny within the universal", Spain's providential destiny had also historical implications. If Spain's history was able to explain Spain's present existence and essence, for the latter is the result of the former, the opposite was also true: Spain's present status could explain Spain's past. In other words, if the accumulation of history explains the result of the Civil War, said result can also explain the layers of Spain's past. It is in this bidirectional and fluid understanding of history that most Francoist sources encounter Roman antiquity, in three main areas.

Firstly, Rome gave Spain a sense of identity and unity: "When the Iberian people came into contact with Rome, that is, with an alien element, for the first time in history the spirit and meaning of what we call Hispanidad sprung", the falangista Almagro Díaz explained in El pueblo español y sudestino (Almagro Díaz, 1950: 43). 
Rome came to create Hispania which became the beginning of Spain's existence and providential mission. This idea would be most strongly defended by Antonio Tovar. Tovar was a classicist and later Rector of the Universidad de Salamanca, who became one of the central men in Falange's role within the regime, as the first director of Radio Nacional, Subsecretary of Press and Propaganda and one of the emissaries of Franco to Hitler. Twenty years later, Tovar would become disenchanted with the regime and turned into a strong liberal critic of Franco. This is what Tovar had to say in Imperio de España (first published in 1936), adding Romanity to Primo de Rivera’s historical conception:

That is why the unity of Spain is never going to be a racist unity, nor of language or culture, but a unity of destiny, achieved by virtue of Romanity, alive only in the moments when Spain is aware of its universal destiny (Tovar, 1941: 17).

Secondly, Rome also brought Spain into a path which would eventually lead to Christianisation, Catholic counter-reformation and, finally, Franco's national crusade against the enemies of the Church. "God is in Romanisation", José María Pemán (1939: 40), a leading Catholic intellectual and writer of the regime, stated. Rome, therefore, set the foundations of Spain's identity as the most Catholic nation, but also as the main defender of the one true faith against any kind of heresy: "Romanisation and Christianity are the forces that create, now and forever, our history, and it must be with fidelity to it that we are to build our political present", Tovar exclaimed in September 1939 (Tovar, 1941: 119). It is important here to note how the emperor Theodosius, born in Coca, Spain, was vindicated also as a Spaniard who, understandably, would establish Christianity as the religion of the Roman Empire, thus completing another step in Spain's Christian destiny (Pemán, 1939: 49; Tovar, 1941: 23; Almagro Díaz, 1950: 51; Duplá, 1999: 344). Let us read how Fernando Valls Taberner saw in Augustus' "pacification" the seed of Spain's Roman and Christian soul: 
Augustus providentially contributed to prepare the path for the propagation and penetration of Christianity, which, alongside Romanity, would become one of the essential elements, better said, the supreme and most transcendent factor in the formation of Spain's soul (Valls Taberner, 1939: 151).

Finally, Rome gave Spain its first taste of empire. Spain's participation in the Roman Empire through figures such as Seneca, Martial, Lucan, Quintilian and the Antonine Emperors prepared it for future imperial grandeur under the Catholic Monarchs and the Habsburg Monarchy (See Ballesteros Gabrois in Jerarqvia n. 2 (1937) and Tovar, 1941: 21-24). Spain learnt its imperial destiny from the best teacher of empire history could ever offer: Rome itself. This is most emphatically explained by the fascist intellectual Ernesto Giménez Caballero in Roma madre (1939):

I only want to remind you of what happened the other time. The other time that Spain dreamed an Empire. The time of the Catholic Monarchs.

Then -in the pre-imperial Spain of the arrows and the yokethere was no other slogan but the title of this book: Rome! Reemerged into the world! Mother Rome! [...] The dream of that Spain: Rebirth! To be the Rome of new times! A dream that, by being dreamt with love and purity, became a reality. It became an Empire.

A dream that is -today- the same as our dream: Rebirth. Resurrection. To see Spain again as Una, Grande, Libre. And like the ideal Rome: "re-emerged into the world". And a "Mother", like Rome. Spain! Spain! Spain! (Giménez Caballero, 1939: XXXI-XXII).

This imperial legacy and teaching of Rome fitted a discourse of authoritarian and caesarist leadership (See Payne, 1987: 193; Moradiellos, 2016: 297). José Antonio Primo de Rivera himself defended this idea (See Duplá, 2003: 79). The bidirectional flow of providential Spanish history is, once more, effective here: Franco must be the $d u x$ of Spain's imperial destiny as were once 
Augustus, Trajan, Pelayo, Charles I and Philip II. Caesarism and imperialism are thus essentially connected in Spain's history, according to the sources, and as is evidenced in "Leyenda del Cesar Visionario" by Federico de Urrutia, published in Edelvives' schoolbook Historia de España: Segundo Grado (1952):

\author{
Resounding shouts of Empire!, \\ lips broken with angst, \\ and through the winds of the world, \\ with meridians trembling, \\ from the virgin America \\ to the far Orient, \\ the name of the Caesar resounded: \\ Franco! Franco! Franco! Franco! \\ (Urrutia in Anonymous, 1952: 219).
}

Conversely, Rome also set the example for Spain to understand how its own national independent identity could be compatible with an imperial universal grandeur. Spain's empire, like Rome's, is to be both national and universal, both urbs and orbis. However much Spain participates in an imperial destiny, whether inside Rome or later, it never loses its sense of uniqueness and independence. Here both Viriathus and Trajan play a key role.

Viriathus is the proof of a pre-Roman substratum of Spanish fierce independence against foreign aggression, as would later be the case against the Napoleonic invasion (see, for example, García y Bellido, 1985: 80), and against atheism and communism in the Civil War. But Viriathus is also the seed of a strong will to conquer and vanquish, which, once refined by Rome, would bring Spain into its imperial destiny. Trajan, on the other hand, is the example of the capability of Spaniards to lead empires into further expansion, but always maintaining a strong and unquestionable Spanish character, which informs Spain's imperial greatness. Similarly, Franco, in leading the national crusade against the enemies of Spain's imperialism and Catholicism, was defending imperialism and Catholicism worldwide as the "Sentry of the West" (See Boyd, 1999: 99). One can infer from Francoist propaganda that from the 
nucleus within the Iberian Peninsula, as Rome did from Latium, Spain had been able in its history to aspire to universal grandeur and power without losing a sense of its own worth, as Viriathus, Trajan and Franco-apparently-demonstrate.

\section{3.}

\section{Caudillo de Nuestra Gloriosa Cruzada: Una Grande y Libre}

As follows from the idea of Spain's historical destiny, the Franco regime appears as the latest episode, perhaps even the culmination, of its providential imperial, Catholic and national greatness, of its "unity of destiny". It is, therefore, understandable that its leader, General Franco, would be regarded as a figure of such excellence and worth that he could stand up to the challenge of leading Spain in its hour of need and subsequent victory. He became the embodiment of Spain itself, that is, of its people, its history, its essence and its providential greatness. Franco was Spain, and Spain was Franco, as a schoolbook from Edelvives implies:

A military man of brilliant history, adorned with the most exalted virtues of our race, our Caudillo was a gift of Providence to unite all our wills and lead the country from triumph to triumph to rescue it from the clutches of Marxism and put it on the path of its future greatness (Anonymous, 1952: 215).

It is in this discourse that Franco appeared as embodying Spanish and human values of the highest standard as a leader of a great nation (See Payne, 1987: 192-193). He was a humble, simple man who wished to lead a calm life of peace and order, but who, in Spain's terrible hour of need, rose from his temperance and led the true Spain against its enemies (see Payne, 1987: 117-118). He appeared as a magnanimous pater patriae, but who was implacable against the enemies of Spain and the Church. His involvement in the political, military and spiritual command of the nation did not stem from his own ambition or pride, but from his duty. It was not personal will, but providential necessity that dictated his 
actions. This portrait of Franco appears as both template for and response to the portrayals of past caudillos, including Viriathus and Trajan, as we shall explore below.

Within this unitarian vision of Spain and Franco as alpha and omega, the motto of the regime, "Una, Grande y Libre" becomes also what Franco must be. As Spain is one, so must Franco unite the nation and eradicate separatisms. As Spain is Great, so must Franco lead Spain to greatness home and abroad, urbi et orbi. As Spain is Free, so must Franco free Spain from its heretic and communist enemies and guarantee the Catholic and imperial force that will liberate Spain in its greatness. In turn, Spain is guaranteed to be Una, Grande y Libre because Franco stands as its caudillo. The same as Germany declared that it was to be "Ein volk, ein Reich, ein Führer", so was Spain destined to be "Una patria, un estado, un caudillo" (One fatherland, one state, one caudillo) (see Payne, 1987: 168-169).

The concept of Spain's providential destiny, Rome's role in shaping it, and the development of the caudillo as virtuous leader and embodiment of the nation inform the portrayals of Viriathus and Trajan during the Franco regime until 1955. The figure of Viriathus as a national caudillo of Spain was illustrated by his capacity to join the pre-Roman peoples of Spain in their resistance, his personal and military virtues as caudillo, and his murder by traitors. Trajan appeared, within a broader appreciation of the Antonine Emperors, as a universal caudillo of Spain, focusing on his essential Spanishness, his direction of Rome away from decadence and his culmination of the Pax Romana, both as internal peace and virtue and as external expansion. The following discussions on Viriathus and Trajan will be structured in three main points that respond to their apparent service to the conception of Spain as Una, Grande y Libre, in their role as eminent caudillos and Spanish precedents of Franco. 


\section{2.}

\section{Viriathus: National caudillo}

In the sources, Viriathus, who fought against Rome between 147 and $139 \mathrm{BC}$, very often appears with the title of caudillo or variations of it, like the verb acaudillar. He was clearly understood as the unquestionable leader of a resistance war against Roman invasion and conquest, who manages to unite the Lusitanians, and by extension the Spaniards, in war. He was understood to be an early example of Spain's independence and strength (see Pastor Muñoz, 2004: 221). In light of this, Viriathus evolved from being "The liberator, one could say, almost of all Spain" in Juan de Mariana's Historia General de España (1606) to "Caudillo of Spain" in Ruiz Carnero's Historia de España (Ruiz Carnero, 1943: 31-32) or "first Spanish caudillo" in Rodrigo Sospedra's Valores encarnados $y$ defendidos por España a lo largo de su historia (Rodrigo Sospedra, 1955: 28), part of the school subject known as Formation of the national spirit 5 . Viriathus' appearance as caudillo, and thus as Franco's historical precedent and counterpart, placed him, as the examples quoted exemplify, at the service of Spain, that is, Spain as Una, Grande y Libre.

\section{1.}

\section{Una: A nation before the nation}

During the early years of the Franco regime, Viriathus is mentioned as uniting the apparently disparate pre-Roman peoples of Iberia into a frontal and strong resistance against Rome. The Iberian peoples were thus aware of belonging to Spain before Spain even existed. In other words, Spain is a nation before its own nationhood. Consequently, the use of the terms España or españoles, to designate those who fought under the "first caudillo of Spain" (see Álvarez Pérez, 1953: 169), is widespread, since Viriathus was "chosen as chief by the Spaniards", José María Pemán explained (Pemán, 1939: 32). It is true that the term lusitanos is often used, as is Portugal, but they are often intercalated with españoles or they

5 See also Pastor Muñoz, 2004: 221 and Prieto Arciniega, 2004: 121. 
are taken to mean a regional area of a broader united community: Iberia-Spain.

This idea of an almost natural or determined territorial and national unity in Iberia-Spain served the regime's ideological defence of Spain as a territorial unity which could not tolerate any regional separatism. Spain was Una, because it had been so even before the Romans arrived. The falangist newspaper La Nueva España dedicated a comic strip series in late 1943 precisely entitled: "The forgers of National Unity: Viriathus" (La Nueva España, 14-11-1943, 21-11-1943, 19-12-1943, 26-12-1943). National unity was, in part, behind the self-ascribed title of "nacionales" by the Franco forces in the Civil War and after. Most probably in relation to this term, in a comic on Viriathus drawn and written by Manuel Gago in 1943, Virathus' fighters against Rome are called "nacionales". This nationalistic and territorial unity already existent under Viriathus would be extended beyond the frontiers of a unified Spain and into an Iberian union of authoritarian states, when the Portuguese dictator Antonio de Oliveira Salazar sent the Portuguese battalion Viriato to fight in the Spanish Civil War alongside Franco. Viriathus, "a common hero" for Spain and Portugal, according to Isidoro Millán in 1937 (Faro de Vigo, 28-111937) ${ }^{6}$, once united Iberians against the threat of Rome and he did so once more against the threat of communism in the Spanish Civil War (see Pastor Muñoz, 2004: 216-217).

\section{2.}

\section{Grande: 200 years of conquest}

Viriathus' greatness and exceptionality is often underlined in the sources. He was a natural military caudillo, a "genius in war", according to Pemán (Pemán, 1939: 32). He led (acaudillar) the resistance against Rome during eight whole years, according to Almagro Díaz (Almagro Díaz, 1950: 44). He was undoubtedly in the line of historical Spanish caudillos up to Franco, in Pericot's mind:

6 This issue opened with the headline "Long live Portugal! Long live Spain!”. 
His strategic acumen, his enveloping movements, his feigned retreats based on great mobility and knowledge of the terrain, his sobriety and resistance, his own personal authority and the fidelity of his soldiers, coincide with the way of acting of other Spanish caudillos until modern times (Pericot, 1950: $343-348)^{7}$.

But his greatness as military caudillo must not be misunderstood as arrogance or a lust for war. Viriathus was, according to our sources, a virtuous humble man, a simple shepherd who had to become caudillo after the terrible atrocities inflicted by the Romans. He was, as Franco, only a caudillo because of providential necessity, and never because of personal will or ambition. Viriathus was "gifted with all the virtues of the Hispanic tribes: fidelity, sobriety and independence", we read in a comic strip published in La Nueva España on the $14^{\text {th }}$ of November 1943. Primarily because of his virtues as caudillo, his resistance, and that of the españoles under him, was of such strength, greatness and pride that it took the Romans two hundred years to conquer Spain, while it took them only seven years to control France, according to Pemán (Pemán, 1939: 31). Spain's pride, independence and greatness in the face of the enemy are thus legendary and superior to that of France, the international bete noire of much Spanish nationalistic rhetoric.

This greatness of Viriathus' Spain would be the seed of Spain's providential history of strength and will in the face of adversity. Therefore, because of Spain's essential Catholicism in the eyes of Francoist discourse, Viriathus, centuries before the birth of Christ, prefigured Spain's service to the one true faith, as another caudillo, Franco, would later. According to Almagro Díaz, Spain's two hundred years of resistance against Rome would finally blossom into Catholic Spain:

7 Quoted in Gil González, 2012: 222. A similar idea is expressed in Proa: Diario de Falange Española y de las JONS, 13-11-36. 
The sacrifice of two hundred years of resistance against Rome and the heroism of the fallen have not been in vain. Because of them, Hispanity, for the first time in its history, fulfils its destiny in preparing the path for God when they take their ideas and their spirit to the entrails of the Roman world (Almagro Díaz, 1950: 48).

\section{3.}

\section{Libre: the resistance against foreign invasion}

Viriathus demonstrated, for Francoist propaganda, the fierce independence and resistance of Spain against foreign and threatening invasion, as would later be the case against Al-Andalus, Napoleonic France and Soviet communism. The relevance of this aspect of foreign aggression must not be overlooked. According to the regime, the military rebellion of July 1936 was due to the unavoidable necessity of defending Spain against its enemies. These enemies were, as seen, communism, atheism and also freemasonry, all understood to be imported evils, for they could not naturally grow in a Spain that was essentially Catholic, imperial and orderly. By virtue of the theory of the anti-Spain, all those who supported or enacted the ideas of these foreign forces were themselves non-Spaniards, and thus to be taken as foreigners. Within this discourse, the Spanish Civil War could be seen as a foreign war within the nation against alien forces, whether from abroad or within Spain. It would be called, after all, a Guerra de Liberación Nacional (War of National Liberation). This is what ultimately informed the comparison made between Franco and Viriathus by Antonio Acosta Pérez in an article entitled "The Republic led us to chaos" in May 1938, almost two years into the Civil War:

On every page of our national history one can find episodes that prove that Spaniards have always been defenders of the integrity and independence of their nation. Franco is a worthy successor of Viriathus. History repeats itself in these moments with extraordinary eloquence. Spain needs the spirits of 
Viriathus and Pelayo to reincarnate in all its authentic children so that they can wrench it, once and for all, from the claws of its enemies (Diario de las Palmas, 09-05-1938) . $^{8}$

It is in light of this rhetoric that Viriathus' fight against invading Rome is explained. It is lurking behind Palacín's address to a fallen unknown falangist in Proa in late 1936: "New Viriathus, you wanted to expel from your homeland the foreigner who wanted to implement laws contrary to the character of the Spanish people" (Proa: Diario de Falange Española y de las JONS, 0412-36). In the same line, in a history schoolbook by Edelvives, Viriathus' resistance appears as a "levantamiento general (general rising)" (Anonymous, 1952: 32), closely mirroring the term of Alzamiento Nacional (National Uprise), used by Francoist propaganda to describe the 1936 coup against the Republic. We also find the following in the falangist newspaper Duero: "Viriato had strengthened the national spirit [espíritu nacional] and punished the boldness of the Romans by gathering a great army" (Duero: Organo de Falange Española Tradicionalista y de las JONS, 10-091943). According to this newspaper, it was precisely the "national spirit", also the focus of a school subject in the Franco regime, that summoned Spaniards to form a "great army" against its enemies". The echoes of Francoist rhetoric defending the 1936 coup d'état are here transparent, as it is in Manuel Gago's comic Viriato (1943), whose second vignette reads:

Viriathus, the Lusitanian shepherd, encourages the nationals who flee from Roman abuses to rise up in arms against the invaders (Gago, 1943).

8 Casariego makes a similar comparison in La Nueva España, 01-101941.

9 A similar rhetoric was also used on the republican side during the Civil War, for example when the Spanish people are compared to Viriathus fighting against Franco, which sold Spain to the foreign influence of Germany and Italy in Ahora, 07-01-1937. See also Libertad: Semanario del Frente, 1937, n.3 and La Libertad, 23-05-1937. 
Spain's weakest spot was the enemy within, the traitor, the anti-Spain, according to Francoist propaganda. For this reason, Viriathus, as leader of Spain and thus embodiment of its strengths and virtues, could never be vanquished by the invading Romans. This "unforgettable Spanish patriot", as the falangist newspaper Duero called him (Duero: Organo de Falange Española Tradicionalista y de las JONS, 10-09-1943), was murdered by his treacherous companions: "And so that great warrior died: by treason and with his eyes closed; since with his eyes open and face to face it could not have happened", José María Pemán explains (Pemán, 1939: $33)^{10}$. Viriathus could have never fallen to enemy hands, but had to be betrayed by the enemies within, his emissaries to Quintus Servilius Caepio, as Spain had been betrayed by the "afrancesados" or by "the collaborationists, as we would now called them", as García y Bellido explicitly mentions in relation to the Napoleonic Wars and the Civil War respectively, as late as 1967 (García y Bellido, 1985: 80). Only by treason can Spain fall, as Viriathus exemplified in Rodrigo Sospedra's words:

[The traitors] killed the first Spanish caudillo of the people in arms while he slept in his tent. Thus was the death of that, tremendously Iberian, national hero, the prototype of Hispanic virtues and standard bearer of our patriotic independence: by treason, in the back and with his eyes closed (Rodrigo Sospedra, 1955: 29)11.

As has been here discussed, Viriathus appeared, during the early years of the Franco regime, as a humble but implacable caudillo who led the unity of Spain into war against the invading Romans during eight years and who would eventually be killed

10 This vision was already prevalent since Roman times, see Pastor Muñoz, 2004: 213.

11 Similarly, the republican side in the Civil War had seen a parallelism between Viriathus being betrayed by his own soldiers and Spain suffering treason by its own 'betraying generals' in Ahora (10-08-1937). 
by the most treacherous enemies within. He was, alongside the resistance by Numantia, according to a schoolbook by Edelvives, the example of a national martyr against the enemies of Spain, who fought courageously for dignity and independence, an example for all Spanish schoolboys (see Álvarez Sanchis and Ruiz Zapatero, 1998: 46 and Prieto Arciniega, 2004: 125). Viriathus, in being a simple but ruthless leader of a Spain under threat, in his unflinching defence of a Spain which was even then Una, Grande $y$ Libre, was also the example, and the precedent, of Francisco Franco as Caudillo de España.

\section{3.}

\section{Trajan: universal caudillo}

Contrarily to Viriathus, Trajan is very rarely called caudillo during the Franco regime. One of the few instances in which he is mentioned as such is by the introducer of fascism to Spain, one of the founders of Falange and later speechwriter of Franco, Ernesto Giménez Caballero in España Nuestra (1943): "Trajan is the caudillo of Spanish Rome” (Giménez Caballero, 1943: 165). There could be many speculative reasons for this scarcity. Firstly, the timid appearance of Trajan in comparison to Viriathus or to later caudillos makes the use of the term less prone to appear. In addition, Trajan often appears as the initiator of a line of Spanish emperors of Rome, which merges his identity into one wider phenomenon, thus overlooking his particularities. Finally, the use of the term emperor in the case of Trajan is compatible with, or even greater than, the term caudillo. The importance of the term emperor to Francoist propaganda must not be overlooked. Franco himself was often compared to Augustus, and Galindo Romero went as far as to call Franco imperator, princeps and pater patriae, as a Spanish equivalent of Augustus (Galindo Romero in Uribe Lacalle, 2011: 368-369)12. That Trajan inaugurated a line of Spanish emperors running through Spain's providential history

12 See also Duplá, 2003: 81-84. 
and perhaps culminating in Franco, is to be seen in Giménez Caballero's words in Roma Madre (1939), an edited compendium of previous articles:

Trajan and Seneca in the ancient Roman world represented the same as Charles V and Loyola in the Catholic Roman world, and perhaps the same as other yet-unknown figures, who will come in their own time to the social Roman world which now takes place (Giménez Caballero, 1939: 79).

But despite the scarceness of the term caudillo, and besides the use of emperor, for Trajan, the regime did show some interest in the figure of the imperator from Italica. The root to much of the Francoist discourse on Trajan is to be found in Santiago Montero Díaz's "Semblanza de Trajano". Montero Diaz was a member of the Juntas de Ofensiva Nacional Sindicalista since the early days and he joined Falange Española Tradicionalista y de las JONS after the Civil War ${ }^{13}$. During this time and as Chair of Ancient History at the Universidad Central in Madrid, he was one of the propagandists of the early Franco regime, which he would gradually come to actively abhor after 1945. It is true that his "Semblanza de Trajano" was first published in 1935, but its broader impact took place when it closed Montero Díaz's book De Caliclés a Trajano, published in 1948. As Duplá rightly remarks, if Montero Díaz had not ascribed to, or at least accepted, the theses of "Semblanza de Trajano", he would not have reprinted it in 1948 (Duplá in Montero Díaz, 2004: IXX). Therefore, Montero Díaz’s portrayal of Trajan, because of its two publishing dates, 1935 and 1948, appears as both programme and guide to what a good Spanish ruler should be in the eyes of imperialistic fascism and at the service of the Spanish nation as Una, Grande y Libre.

13 For a biography of Montero Díaz see Duplás introduction to Montero Díaz, 2004. 


\section{1.}

\section{Una: A unique Spanish identity}

Trajan's service to Spanish unity could hardly be territorial or communal, as in the case of Viriathus. His actions as emperor fell within the remit of the mighty Roman Empire, which transcended territorial or communal enclosures. He could not be seen as a national caudillo because his role and destiny were universal. His Spanish unity lay in his Spanish identity and essence. His own Spanishness is what marked his actions, virtues and decisions: Trajan was "Viriathus' fellow countryman, simple and popular, such Spanish virtues", Colodrón Morán wrote in the falangist newspaper La Nueva España in May 1938 (La Nueva España, 31-05-1938). Trajan, as emperor, could be nothing but a Spanish emperor of Rome. His was a unity of national spirit: "Trajan represented a spirit, a way of being and the intimate essence of his province, where there already was a latent Spain", Montero Díaz explains (Montero Díaz, 2004: 112)14. Consequently, Trajan's virtues were those essentially pertaining to any true and great Spaniard, as Colodrón Morán explained in an article entitled "Spain in the Empire":

The spirit of camaraderie he learnt in Spain makes him address consuls and shepherds as colleagues. An authentically Spanish simplicity infiltrates Rome mixed with ingenious kindness with Trajan and his wife, the empress Plotina; and provincial Spanish health and honesty sprouts and blossoms as an exotic flower that acclimatises in the once horrendous and foul palace of Domitian (La Nueva España, 31-05-1938).

In the sources, Trajan appears as humble, prudent and magnanimous, but also implacable with those who abused their status or his imperial dignity. These innately Spanish virtues of Trajan coincide with those that others ascribed to Franco himself-and

14 Montero Díaz will go on to explain that Trajan's Spanishness stems from his innate senequismo, echoing Ganivet's Idearium Español, 1897, see Montero Díaz, 2004: 113-114. 
Viriathus. Trajan appears in Montero Díaz as the epitome of Spanish unity of spirit and of the virtues of any great Spanish leader, thus setting a path for future caudillos of the Spanish nation:

To institute Caesarism and unity in the world. That is the enormous and providential task, which the Republic initiates and Trajan concludes.

Trajan means, therefore, in the history of Rome, the happy culmination of its universal work: The conclusion and consolidation of a task of centuries and centuries. But Trajan is at the same time -as we have already seen- a Spaniard; and not just any Spaniard, but an archetype of a Spaniard (Montero Díaz, 2004: 126).

\section{2.}

\section{Grande: From Pax Romana to Pax Hispana}

In his Spanishness, Trajan was able to bring unity to a Rome in crisis, according to the sources. He brought an end to Roman decline and decadence, and installed, because of his innate Spanish virtues, a new Rome of order and greatness. Montero Díaz sees him as the example of a hero of historic times, when "the hero is the expression of destiny", in opposition to those of epic or tragic times (Montero Díaz, 2004: 111). Trajan thus embodied his own and Rome's destiny to greatness, and, consequently, Spain's. Trajan was the "faithful interpreter of the irrevocable and unique destiny of his time", Montero Díaz writes (Montero Díaz, 2004: 120). Montero's own book De Caliclés a Trajano describes the alleged improvement from democratic systems in Ancient Greece to the personalistic rule of the military emperor Trajan, the historical hero. Therefore, Trajan appears as a fitting example for a regime that was born in an uprising against a legitimate democratic republic and installed Franco as its caudillo. "Caesarism is culminated with Trajan”, Montero Díaz exclaims (Montero Díaz, 2004: 123). 
But despite this destined greatness, which is Rome's and Spain's too, Trajan also re-established virtue within the Roman Empire. He brought the resurrection and culmination of Augustus' Pax Romana, according to Montero Díaz and Colod rón Morán (Montero Díaz, 2004: 123; Colodrón Morán in La Nueva España, 31-05-1938). In doing so, Trajan reinstalled the greatness of Rome's Golden Age, and with it a sense of conservative correctness and order. Coincidentally, Galindo Romero and Valls Taberner saw Franco as also establishing a Pax Romana as Augustus' did, after the decadence of Republican Spain (Galindo Romero in Uribe Lacalle, 2011: 368-369; Valls Taberner, 1939: 145-151). Franco's regime would indeed celebrate "Twenty five years of peace" in 1964. According to Francoist discourse, both Trajan and Franco reinstituted the greatness of the society they led, following the Augustan model of military strength, personal authority, social morality and stately power against the decadence of more corrupt systems.

From 1936 until the end of the Second World War in 1945, the concepts of Pax Romana, of an Augustan Golden Age and of Romanity were understandably linked to international fascism, to which the majority of members of Falange either ascribed or were sympathetic (see, for example, Tovar, 1941: 24 or Giménez Caballero, 1939). Trajan thus played an essential role in Francoist discourse of fascist international greatness: "Mother Rome, Spain is united with you again, as in the column of Trajan's forum!", José María Pemán exclaimed in Cadiz in August 1936 (La Unión (Sevilla), 08-09-1936). Trajan became a precursor of Franco's own service to the cause of Mussolinian Romanità. He became, as Franco, the necessary Spanish link that served as a guarantee for the victory of international fascism in both military and spiritual terms. The senior falangista Rafael Sánchez Mazas used Trajan as an exemplum in his salutation to-Mussolini's-Rome just weeks after the end of the Spanish Civil War, when Franco's forces claimed to have vanquished the anti-Spain:

The eternal youth of Italy and the eternal youth of Spain, fought and triumphed again against the barbarians. When 
your legionaries in the Spanish War paraded recently before the Duce, at the hour of our entry into Madrid through the path of Empire, they reminded us of how Trajan, Roman Emperor born in Seville, led Roman weapons to victory and widened the Empire (La Nueva España, 22-04-1939).

The alignment of Romanity, fascist Romanitá, Trajan and Spanish imperial and spiritual greatness found its culmination with the accession of Ion Antonescu to power in Romania in September 1940. The fascist potential of this event—and Trajan's influence in it-had already been enthusiastically hailed by the newspaper Falange in June 1940:

Ancient Dacia returns to Rome. The Latinity that Trajan Optimus-born in Spain to be the light and strength of the Roman Empire-infused in its soil-Hispano-Roman blood-flourishes again in Romania for being the one who best bears the name of Latinity.

We are in the midst of Spenglerian years. Romania appears as another country on the list that enlarges the record of Europe's momentous historical mission. The only solution Spengler sees for the rejuvenation of this old world is Caesarism (Falange [Las Palmas], 27-06-1940).

Hispano-fascists thus saw in the historical example of the Hispano-Roman Trajan, conqueror of Dacia, the civilising power of Spain at the service of Rome. They saw it as understandable that a fascist brotherhood that had united Rome, Spain and Romania would blossom once more in 1940, under the providential aegis and presence of the civilising caudillo, Trajan:

In any crusade launched against soviet Russia, the Romanian people necessarily had to participate, as its national destiny demands, in the terms the emperor Trajan traced it nineteen centuries ago (Fotos, 09-05-1942). 


\section{3.}

\section{Libre: The freedom of force}

Trajan, as expansive emperor, also follows another aspect of the Augustan Pax Romana for Francoist discourse: imperial expansion. Trajan was seen as a precedent of future Spanish imperialism and emperors, an essential step in Spain's historical destiny. Trajan, in his expansion towards Dacia, Germany and the Middle East, became the Spanish culmination of Rome's essential imperialism. According to Montero Diaz: "He conquers forever" (Montero Díaz, 2004: 120). He later adds:

Spain, which enriches the Empire, which provides it with a century of poets and thinkers, which strengthens its legions and assimilates its spirit; Spain, blood of Empire and Empire herself since the years of Augustus, completes and concludes through Trajan the Roman task (Montero Díaz, 2004: 126).

This "conquering forever" refers to his ability to assimilate a territory into the Roman world to the point that it would later take its own name when calling itself Romania. This assimilation of the Roman territories into a unique Romanity, culminated and achieved by Trajan the Spaniard, is not dissimilar to how many saw in the Spanish Empire the establishment of an enduring Hispanidad. This link is explicitly made by Ernesto Giménez Caballero in Yugo, in June 1942:

In Andalusia we jumped from Trajan - the conqueror of Romania in the name of Rome - to the conquistadors who in the name of Rome conquered America: in the renaissance of that happy Trajan antiquity (Yugo, 30-06-1942).

Spain, it seems, like Trajan, "conquers forever". This is due to what Tovar believed was the legacy of Romanisation: a unity based on a common spirit, and not on a race, language or territory. Trajan himself established the "first universal empire of a Hispanic sense", according to Almagro Díaz (Almagro Díaz, 
1950: 47), bringing, alongside Hadrian, in the eyes of Tovar, the beginning of this Spanish version of spiritual empire:

Trajan and Hadrian, the two great Spanish emperors, come, after the imperial decadence of their predecessors, to represent the zenith of the Empire and of Rome [...] that then reaches its maximum borders in the far Tigris or in the barbarous land of Dacia, which because of the work of Trajan, the Spaniard, will remain forever-Romania-within Romanity. In the days of Trajan and Hadrian, the empire lives its centrality, a veiled, austere, Spanish centrality (Tovar, 1941: 21) 1 .

It is through the offensive pursuit and fulfilment of this spiritual imperialism that Spain could be free to follow its destiny, vanquishing its own enemies, be this in the outer frontiers of Rome, America, Europe or Christendom ${ }^{16}$. Only its greatest leaders, with a vision for the universal and Spain's providential history, could fulfil Spain's imperial destiny and establish a Pax Hispana, be this Trajan, Philip II or Franco himself: "the Spanish people rises once more today against renunciation and cowardice with imperial airs", Tovar wrote about the emerging regime (Tovar, 1941: 10).

Trajan thus appeared to Francoist discourse as Spain's original universal caudillo. In his caution, magnanimity and humility, combined with his implacability, discipline and righteousness, he was able to represent a Spanish unity of spirit within a Rome he had rescued from its downfall and placed in the offensive pursuit of a spiritual empire, thus guaranteeing its freedom. Trajan appears as the precedent of a humble but unflinching Franco, who in his own pursuit of the spiritual empire of Spanishness and Catholicism is able to free Spain from the previous dangers of Eastern decadence and soviet influence. Spain, with Trajan and Franco, was able to play its imperial role within the universal.

15 Rodrigo Sospedra agrees with this reading, see Rodrigo Sospedra, 1955: 34.

16 For a discussion on the concept of empire during the early Franco regime, see Box, 2013. 


\section{4.}

\section{Conclusion: Caudillos de España}

The voices in charge of education and propagandistic discourse within Francisco Franco's regime, saw it necessary to propose Viriathus and Trajan as two examples of Spanish caudillos in Spain's providential history, whose destiny had been fulfilled by the military strength and magnanimity of Francisco Franco, Caudillo de España. Because of their essence as providential Spanish leaders, Viriathus and Trajan served Spain as Una, Grande y Libre, following the national conception of the Francoist dictatorship. Their historical and personal circumstances did not change this service to Spain, they just altered what Spain's oneness, greatness and freedom entailed. Viriathus thus came to embody and defend a Spain before Spain which was united against the threat of an invading Rome by a great sense of independence and dignity that guaranteed its national freedom up to the moment when the enemy within committed treason in killing Viriathus. Conversely, Trajan represented a unity of the Spanish spirit, the greatness of Spanish virtues, social order, Romanità and caesarism and the freedom guaranteed by Spanish expansion in the pursuit and defence of Spain's spiritual empire. To Franco's regime, both Viriathus and Trajan were essential Spanish caudillos from two complementary standpoints: the national and the universal. Franco, as providential Generalísimo of Spain's destiny, was the synthesis of these two caudillos and Spanish perspectives. Franco was at once Viriathus and Trajan, national and universal caudillo, the Caudillo of Spain by the Grace of God. As such, he became the embodiment of Spain's soul as both Spanish and Roman, national and universal, a Spanish-Roman soul José María Pemán so vehemently exalted in 1939:

And when we salute each other by raising our arms, we do not accept with it a passing fad of today, but we greet "in the Roman way", as our ancestors greeted each other many centuries ago. Because if we are "Catholic and Roman" in our religion, in civil matters we are also "Spanish and Roman". Roman is for us, in everything, before God and men, our second surname (Pemán, 1939: 41). 


\section{Bibliography}

Anonymous (1952): Historia de España: Segundo grado. Zaragoza: Edelvives.

Almagro Díaz, A. (1950): El pueblo español y su destino. Madrid: Gráfica Anja.

Álvarez Junco, J. (2011): Spanish identity in the age of nations. Manchester: Manchester University Press.

Álvarez Pérez, A. (1953): Enciclopedia intuitiva, sintética y práctica. Zamora: Tipografía comercial.

Box, Z. (2013): "Spanish Imperial Destiny: The Concept of Empire during Early Francoism", Wendy Gosselin (trans.). Contributions to the History of Concepts. Vol. 8. 1: 89-106.

Boyd, C.P. (1999): History, politics, and culture, 1936-1975, in: D.T. Gies (ed.) The Cambridge companion to modern Spanish culture. Cambridge: Cambridge University Press: 86-103.

Duplá, A. (1993): Notas sobre fascismo y mundo antiguo en España in II Congreso peninsular de História Antiga: Coimbra, 18 a 20 de outubro de 1990: Actas: 337-352.

Duplá, A. (2004): Falange e historia antigua in F. Wulff and M. Álvarez Martí-Aguilar (eds.). Antigüedad y franquismo (1936-1975). Málaga: Centro de Ediciones de la Diputación de Málaga: 75-94. Gago, M. (1943): Viriato. Barcelona: Marco.

Ganivet, A. (1897): Idearium español. Granada: Viuda e Hijos de Sabatel.

García y Bellido, A. (1985): Veinticinco estampas de la España Antigua. Madrid: Espasa-Calpe.

Gil González, F. (2012): "El uso de la figura de Viriato en la pedagogía franquista". Estudios de historia de España 14: 213-230.

Giménez Caballero, E. (1939): Roma madre. Madrid: Jerarqvía.

Giménez Caballero, E. (1943): España nuestra: El libro de las juventudes españolas.

Madrid: Vicesecretaria de Educación Popular. Cortadella i Morral, J. and Prieto Arciniega, A. (2005): "Trajano, optimus princeps de la España franquista”, in: L. Hernández Guerra (ed.) La Hispania de los Antoninos (98-180): Actas del II Congreso Internacional de Historia Antigua. Valladolid: Universidad de Valladolid: 537-544. 
Montero Díaz, S. (2004): De Caliclés a Trajano: estudios sobre historia política del mundo antiguo.A. Duplá (ed.). Pamplona: Urgoiti.

Moradiellos, E. (2016): "La doctrina del caudillaje en España: legitimidad política y poder carismático durante el franquismo". Hispania. Vol. LXXVI. 254: 789-817.

Pastor Muñoz, M. (2004): Viriato: El héroe hispano que luchó por la libertad de su pueblo. Madrid: La Esfera de los Libros.

Payne, S.G. (1987): The Franco regime, 1936-1975. Madison: University of Wisconsin.

Pemán, J.M. (1939): La historia de España contada con sencillez: para los niños y para muchos que no lo son. Cádiz; Madrid: Escelicer.

Prieto Arciniega, A. (2004): La Antigüedad en la enseñanza franquista (1938-1953), in: F. Wulff and M. Álvarez Martí-Aguilar (eds.) Antigüedad y franquismo (1936-1975). Málaga: Centro de Ediciones de la Diputación de Málaga: 111-134.

Primo de Rivera, J.A. (2007): Obras completas: escritos y discursos. Vol. 2. Madrid: Plataforma 2003.

Rodrigo Sospedra, A. (1955): Valores encarnados y defendidos por España a lo largo de su historia. Valencia: Gior.

Romero Tobar, L. (ed.) (2013): Temas literarios hispánicos. Vol. 1. Zaragoza: Prensas de la Universidad de Zaragoza.

Ruiz Carnero, R. (1943): Historia de España. Madrid: Editorial Hernando.

Ruiz Zapatero, G. and Álvarez Sanchís, J.R. (1998): “España y los españoles hace dos mil años según el bachillerato franquista (período 1936-1953)". Iberia: Revista de la Antigüedad 1:37-52.

Tovar, A. (1941): El Imperio de España. Madrid: Afrodisio Aguado.

Uribe Lacalle, E. (ed.) (2011): Jerarqvía, la revista negra de la Falange: Pamplona, 1936-1938. Madrid: Barbarroja.

Valls i Taberner, F. (1939): Reafirmación espiritual de España. Madrid: Juventud.

Wulff, F. and Álvarez Martí-Aguilar, M. (eds.) (2003): Antigüedad y franquismo (1936-1975). Málaga: Centro de Ediciones de la Diputación de Málaga. 